\title{
Identity Discordianism under the Trepidation and Duplicity of Human Essence: A Trenchant Investigation on Luigi Pirandello's War
}

\author{
Noorbakhsh Hooti \\ English Department, Faculty of Arts, Razi University, 6714967346, Kermanshah, Iran \\ Yazdan Mahmoudi \\ Razi University, Kermanshah, Iran,
}

\begin{abstract}
This study makes an attempt to demystify the sense of great tragedy of disoriented identity of human essence in Luigi Pirandello's war that seems to be a high significant issue in theme of the story which may have been notified by few researchers. This paper is destined to analyze the agonized human soul with his sanctimonious faiths, under the sense of interminable intimidation, fumbling in the oozy vortex of wars to erect his susceptible identity which seems to have had irretrievable repercussions for him. It exposes the rotten identity in extremism, ethnocentrism, quasi-pacifism, triumphalism and despotism. Ultimately, the study will investigate subversive policies and also have a glance on the sense of undecidabilty and none-belonging of human soul and the chaotic mind covered with a black shadow of quandary which struggles to discover his nebulous destiny in hazardously devastating wars. Indeed, this study makes an effort to elucidate that the occult human essence is enchained by the imposed socio-mental pressures and cannot have a steady reflection of garbled human demeanor.
\end{abstract}

Index Terms - identity, war, tortured soul, Pirandello, undecideability

\section{INTRODUCTION}

Pirandello deemed human identity as an obliviated entity. The enmeshed human in the labyrinth of diverse notions and mental perplexities seem to have no logical and realistic awareness of the concept of identity. The identity which is encaged by the human inherent apprehension and his multi-faced essence makes him seek his specious utopia in dystopian wars by trampling socio-ethical norms. Fearon (1999, p.1) claimed, "despite this vastly increased and broadranging interest in identity, the concept itself remains something of an enigma." As a matter of fact, trite occurrences can sometimes have deep and tremendous impact on vulnerable human soul.

$20^{\text {th }}$ and $21^{\text {st }}$ Centuries have been the Ages of domination of egocentrism and flourishing insatiable enthusiasm of the authorities, latent under the counterfeit mask of sham realism, threatening the spiritually destroyed human essence. As Bloomfield and Reilly (1998, p. 9) observed:

A striking characteristic of such internal conflict is its sheer persistence. And this arises because origins often lie in deep- seated issue of identity. In this respect, the term ethic conflict is often invoked. Ethnicity is a broad concept, covering a multiplicity of elements: race, culture, religion, heritage, history, language, and so on. But at bottom, these are all identity issues. What they fuel is termed identity- related conflict-in short, conflict over any concept around which a community of people focuses its fundamental identity and sense of itself as a group, and over which it chooses or feels compelled, to resort to violent means to protect that identity under threat.

Therefore, this study strives to delineate the phobia-stricken being that seems to have no cognition of the quasimeaningless terms like altruism and enlightenment, and in a tragic hallucination just pretends to be aware of the authentic meaning of human rights. The human being seems to be just the reincarnation of primordial wrapped-minded man. Actually, the stagnant rabid mind of negligent man swells the inordinate pressure of some foisted expressions, which are not tenable anymore for the nascent mentality of modern mass. To be honest, macabre propensity of irremediable intensifying motions is emanated from moribund strategies of tyrants, which may trigger looming the raging agitation of ill-fated society and obfuscated soul that can be known as the center of cumulative problems of the modern world. It is a morass, which may foment the oppressed society to breakout vitriolic pandemonium; the society which may undergo even a poignant metamorphosis that can exacerbate the unmitigated umbrage of human soul.

\section{IDENTITY DISCORDIANISM SALIENCE}

If we introspect the human essence, we may come to know that identity is a blind and elusive term, which may have been ill-rooted in human infected mind. The perplexity of human mind makes us bring up fluid interpretations about this inextricable and numerously multi-viewed term, which sometimes seems to go beyond the human capacities. The 
human that is compelled to carry this burdensome trait under a relentlessly pessimistic insight with a frightening intensity, struggles to conceptualize his eroded identity in an invidious morass. Indeed, the contemporary human is facing preordained wars and the latent anti-social context. The whimpering being strives to preserve his tantalized ego by improper implementations of pseudo-meditative actions. Feeley and Rubin $(2008$, p. 7$)$ delineate the significance of lost identity of the discombobulated soul in the modern time: "identity is one of modernity's most contested concept, not only on its own terms, but because it implicates our theories of the self". A meta-analysis of ambiguous human demeanor divulges the depersonalized personality of exploited human essence under the contaminated approaches of policy makers that formulate the society motions. The demagogues with ever-changing tactics find mutilating wars as safe havens and under none-integrative notions just feign to seek holism and integration. They struggle to indoctrinate their gloomy ideologies in others with the bloody [modern hackneyed terms] commitment and denunciation of the wars that are initiated by their officiously life threatening actions. As a matter of fact, if one infiltrates into the sub layers of human essence, one will find human being as a stoic pre-constructed mass, which is already synchronized to obey the pre- planned schemes and malignant established concepts that are embedded in human mind. The human impoverished perception of life under the invariant belligerency is woven within human inner demon without ruminating on pernicious ramifications of his delusional aims. Therefore; the modern man can be known as the epitome of an entity with lots of unmet expectations that aimlessly wanders in the stampede of dismayed world. Man seems to be the slave of the rotten thoughts of the authorities, who dramatize the soulless beings in an invidious ending drama. Curtis (2006) tries to imply this matter: "'on face value this fragment proposes that war is the determining principle in the flux of the cosmos; that life is in essence a conflictual struggle". (p.1)

Pirandello in the story tries to protrude the malignant impacts of wars on subservient people's lives, specially the bourgeoisie, by dramatizing the real life and utilizing quasi-visionary characters. The schizophrenic characters in a compartment, as if are entangled in a limbo, oscillating between reality and chimerical world, feeling a fatal shadow of melancholy and skepticism like the sword of Damocles hanging over their flimsy lives. The bummed characters as though are being burned and sizzling in the furnace of catastrophic wars. As a matter of fact, the intensified incredulity to those, who believe in inherent mechanism of waging wars, can be inferred in the inalienable trepidation of the characters in Pirandello's war. Indeed, the author struggles to depict a portrait of the escapist man under the perpetual tension and unfathomable demoralization of prostrated soul that wishes to fortify the devaluated values in imperialism. The human being that delves into inauthentic life style to reach equanimity and polemic opaque facticity by deracinating his mental and spiritual world. The following extract from the short story gives the expository ambience of the war-stricken families:

At dawn, in a stuffy and smoky second-class carriage in which five people had already spent the night, a bulky woman in deep mourning was hoisted in - almost like a shapeless bundle. Behind her puffing and moaning, followed her husband - a tiny man, thin and weakly, his face death-white, his eyes small and bright and looking shy and uneasy.

And he felt it his duty to explain to his traveling companions that the poor woman was to be pitied, for the war was taking away from her only son...

"You should thank God that your son is only leaving now for the front. Mine had been sent there the first day of the war. He has already come back twice wounded and been sent back again to the front." (Nowruzi and Brjandi, 2011, pp. 68-9)

The above words show the apprehensive and melancholic hearts of the families, who find themselves stuck in a world of appreciation and depreciation of social responsibility by the name of War. Hooti (2012, p. 4308) eruditely opines:

Pirandello in his War gives a vivid picture of the worries of war. He tries to divulge the hidden agony of the parents, whose sons are either shedding blood or getting killed in the battle fields. They know the futility of the war. Indeed, they are well aware of the politicized connotations of the fossilized normative terms like martyrdom, honor, heroism and patriotism, but still keep quiet and try to console themselves with these honey coated phrases.

Therefore, moronism and abrogated self-actualization of modern man give rise to unconsciousness-growth that bring about uncovering painful facets of transpersonal agonies; actually, the imbalanced multi-slit and ideological sentience of power holders with their permanent shibboleth of reconciliation under a strangulating flux have caused a disastrous upheaval, which is actually a falsified turn-based strategy that is followed by all demagogues. As a matter of fact, the concept value is an oppressed term which may have been treacherously misinterpreted by the inhumane perspective of human immanence. The term, which brings a sense of belongingness and the cognizance of a paramount existential perception may result in self-actualization of harassed plebeian and the classless society that are toppled by the corecenteredness and disequilibrium of modern human soul. As Stewart (2009, p.14) asserts: "a public policy constructs a sense of reality by orienting both observers and participants in a kind of emotional space. The values it represents are the mechanisms of this orientation-sometimes explicit, sometimes implicit". Considering multi nature of the pestilential modernity of modern world, there may be a harassing feeling, where there is a vestige of [distorted] values due to the inverted rationalism of fanatic soul; there may be murky signs of filthy policies and prevailing violence. Indeed, modern man somehow believes in militarized values; that is, a concatenated network of binary values that may be the central expedient of latent reprehensible facets of anti-communal oppression, demoralized rectitude and spiritual duress, which have embroiled the relentless soul. 
So it can be construed that human understanding is grounded based on a baseless originality in a bewilderingly diverse single path that results in imperceptible decadence. Truthfully, Pirandello utilized a train to show the world which is heading to a predetermined destination that ultimately leads to extermination. The path that under the oppressive silence of fluster, may end in schism within subjugated society and war - maximizer policies which are on the foundation of imperfection of fatal flaws; on the other hand, some self-ordained monarchies with a dreadful intensity believe in probabilism and urge that the cosmos has to be changed by initiating destructive wars to reach the specious meliorism. Therefore, in modern times enlightenment, the multi-defined term, seems to pave the way for the dominant class with lots of aporetic variety of pseudo-enlightened notions, just with fervent desires strive to modernize slavery, the mental bondage, a systemized never ending slavery, which has spawned titanism and cross-social vanquishment. Indeed, dusty thoughts of mankind have been buried by disunity and hollowness of human essence, the man that seems to be entangled in a stalemate and lacks an intellectual perception of coherent identification and in status quo can expect the unexpected situation manumit his unconscious conscience. Truthfully, toppled society under the juggernaut of immutable egocentrism, in a harrowing exertion, flounders to unleash its indeterminate destiny which is trampled by harassingly imprudent approaches and languorous mentality of the authorities. As Gat (1989, p.139) avers:

One of the most striking impressions in reading the works of the military thinkers of the Enlightenment is the allembedding uniformity of their theoretical outlook. They differed, to be sure, in many other respects; for example, their spheres of interest varied and underwent considerable change, and they were deeply divided on their annual military outlook and ideas. However, they did not differ in the fundamentals of their guiding objective-the search for a general theory of war-which derived from their intellectual environment.

It may seem that Pirandello wishes to presage that man is drowning into the mire of the disparaging wars. The enervated mankind that alleges to fight terrorism by doing terrorist actions, the manner that does not correspond with reality, and as if he is watching the world by a blindfold. In modern times, based on a reversed democratic accountability, the abused term 'value' has been construed as war waging, carnage, ethnocentrism and fanaticism. Hence, as we observe in our time, the countries which have the most murderous tendencies are the most valued ones. The countries with numerous reprehensible positions are the political actors of rancid nations. Hurrell (2007, p. 165) gives a vey pertinent opinion on the falsified justification of initiating wars: "the urgency of debates about collective security comes, on the one side, from the many different forms of wars, violence and insecurity. But it also comes from the continued rationality of war and of the utility of coercive force." Therefore, the pre-organized concepts like chauvinism and dignity, despite their ostentatious facets, seem to be nilpotent expression. The falsified dignity which is under threat and must be scrupulously used, the term that is under the menace of deceptive transcendence and abnormal-consistent outlooks and is used as a perpetual expedient to stir up ordinary people, upholding authorities' maliciously established aims. Actually, they struggle to penetrate the blind spots of susceptible human spirituality by covering on their sanctimonious mindfulness. On the other hand, considering the degrees of humanity and multiple complexity of modern human excruciated and pauperized essence, people are role-playing to scour the dreadful possible epiphenomena of egocentrism under the fictitious disguise of dignity and chauvinism:

...Isn't it natural that is should be so, as after all they must look upon us as upon old boys who cannot move anymore and must stay at home? If country exists, if country is a natural necessity, like bread, of which each of us must eat in order not to die of hunger, somebody must go to defend it. (Nowruzi and Birjandi, 2011, p.71)

Hooti (2012, p. 4308-9) further aptly avers:

The world political figures know the weak points of the common people. They know that an emotionally fabricated pertinent propaganda with the predetermined brainwashed expressions, founded circumstantially calculated and in synchrony with the need of time, can easily make an aficionado army out of them to secure their privileged sociopolitical authority.

\section{SubVersive Policies: VAgue Future}

Authorities' malism like guidelines have escalated the vulnerability of their fire-powered positions to imminent fiasco. On the other hand, infra-structural exasperation to quasi-glorifying wars may trigger to collapse the universal totalitarianism and may lead to a range of irretrievable aftermath. Actually, the sense of survivability, which is one of the consequences of self-awareness and spiritual renaissance of debilitated human soul can put an end to the illicit positions of the tyrants. In fact, the incomplete worldwide capacity of none-speculative decisions of decision makers to reach far-reaching targets can be the pivotal conflict of the perturbed world, the repressed world, which is covered by the murky veil of insularity of the autocrats that have brought forth an inexpressible suffer of mass panic for the human that is lost in the abyss world of annihilation. Hence, the most terrifying foe of mankind is human itself, that fumbles to discover the answers of unanswered questions by doing irreducibly objectionable actions, which impel him to make a future that may trend in horrendous sustenance of subversive uniformity and may ultimately lead to concluding awesomely uncompromising treaties and war-preaching nations, and deceitfully imposing these nations to the classless class of society. Thus, predilection of bellicose modern secular nation which is equipped with militarized approaches and centralized concepts of dehumanization are the self-evident repercussions of vague worries of the modern mass that egotistical war-based decisions are regarded as optimal strategy. So, the misery-drenched society is observing the 
prescient tangible fragility of encroaching nations, which can be construed as the fundamental reason of epistemological bankruptcy of the authorities. Wallenateen (2002, p. 13) believes: "there are frequent statements on the inevitability of conflict, violence and war. Indeed, finding solutions may often be difficult. This difficulty not only arises out of political constraints, but can also be due to a lack of insight or imagination." In fact, man seems to be in an indefensible terror of painful inability to control the terrifying repercussions of the irrational and ruling iconoclastic creeds of the authorities that have shrouded modern society, which is cordoned by the nemesis of misery.

As a matter of fact, modern world is under the threat of weapons of mass destruction, and no matter who initiates the violence, today's world is being jeopardized by the vexations ghost of imminent wars. More obviously, modern world is the victim of distorted values, delinquency and misapprehension of the demagogues that ruthlessly continue their liberty -spoiling and war preaching actions. From the vantage point of routinizing wars in modern society, it is flagrant that international expansion of recalcitrance is to consolidate the competitive transcendence, which is one of the crucial and determinant outcomes of spiritual deficiency and simulated supremacy of war platters, which can be embodied as a undeniable failure of subversive pacifism and incongruousness of determinant perspectives of those, who wish to formulate not only our vulnerable world destiny but also the cosmos by making scandalously contradictive policies. As a matter of fact, man is suffering from ineluctably continuing conflicts and horribly tangible aftermath of the predicaments, which have put the world on the steep of imminent decadence.

Truthfully, one of the other pivotal numerous complexities that modern world is encountered with, is the recurrent debacle of disruptive solutions, which is intended to obviate the resilient problems and destructive dimensions of deliberative injustice toward society. With respect to the flagrant incompetent conduct of those maliciously reborn selfordained autocracies that can be known as the epitome of contemporary slaveholders, a society may come across the emancipatory pressure of enslaved soul to achieve fallacious sublimity, that may be, as previously mentioned, one of the reasons that indicates the schism between a servile society and a destabilized predominant tyranny. Lipschutz (2000, p.1) beautifully explains this matter:

Political change and economic globalization enhance the position of some groups and classes and erode that of others. Liberalization and structural reform reduce the welfare role of the state and cast citizens out on their own. As the state loses interest in the well-being of its citizens, its citizens lose interest in the well-being of the state. They look elsewhere for sources of identity and focus for their loyalty.

\section{LATENT DEMENTIA UNDER THE TREACHEROUS SENSE OF UNDECIDABILITYD}

A great number of conceptual and epistemological books and articles may have been printed on the futuristic decidability of invincible man, which can be interpreted as an asymmetrical oxymoron with the ambiguity-shrouded mind of human being. The man seems to be the constellation of evanescent and undisciplined decisions, who has ambivalent vision toward even veritable phenomena that have brought him a torturous sense of paranoiac life. The preoccupied man in the slave-driven society under the malaise of non-liberal democracy, with emancipatory recalcitrance strives to maintain his quasi- invincibility and non-renewable destroyed spirituality. Considering the severity of immanent none-belonging of shackled soul and multiplicity of intractable problem-intensifying norms, under the expected abnormality and destructive dysfunctionality of suppressed identity, eternal utopianism of human soul can be interpreted as cryptic self-circumvention, that pejoratively seek serenity in unrealistic aspirations and fallacious decisions, which have propagated traumatic injuries and self-uncertainty for disoriented man. Holsti (1998, p.12) tries to specify that human deviant behavior is one of the reasons of disastrous wars, as he says "Academic researches, peace movements, and many politicians for quite understandable reasons have depicted war variously as a disease, as a catastrophe, as a crime, in brief, as a form of deviant behavior."

Pirandello gives a vivid picture of distressed people, where there is constantly a look into the tortured soul of flabbergasted being with a poignant vision, in which the characters of the story seem to suffer from consternation and struggle to exonerate themselves with prevaricated responses. Actually, the author strives to feature the demented mind of the uncertain man that under the pressure of multiple feelings, aimlessly wishes to fulfill his equivocated ambitions in wars. The focal point of this matter is where Pirandello wishes to depict a flagrant paradox of sanctimonious doctrines by juxtaposing hysterical characters that under anguish and terror of oscillation pretend to believe in self-sacrifice and also lackadaisically look at it as peculiar fact, as the following extract of the story shows:

"True...true...," sighted the embarrassed husband, "but suppose (of course we all hope it will never be your case) a father has two sons at the font and he loses one of the, there is still one left to console him... while..."

"Yes," answered the other, getting cross, "a son left to console him but a son left for whom he must survive, while in the case of the father of an only son if the son dies the father can die too and put an end to his distress.

Now at our age, the love of our Country is still great, of course, but stronger than it is the love for our children.

He shook his light fawn coat so as to show it; his livid lip over his missing teeth was trembling, his eyes were watery and motionless, and soon after he ended with a shrill laugh which might well have been a sob. (Nowruzi and Birjandi, 2011, pp. 70-2)

As a matter of fact, opponent conformity of human erratic behavior, under the terribly invigorated corruption of his creeds has brought forth a terrifying sense of discombobulation. The commotion which is being intensified by the nonconforming- based and conflict making decisions in the conflicting world that is one of the results of the 
contradictions between the human concreted beliefs and his instable demeanor. Actually, a contradictive mendacity is governed on the world, which is defying serenity, and the man that is facing poignant dilemmas and maniacally prefers to make fluctuating decisions that threat his vulnerable identity.

\section{CONCLUSION}

Modern man has faced manifold dilemmas of discovering his invalidated vulnerable identity; the identity that apparently has lost its identity and is environed by ineluctable horrible ramifications of despotism and destructive decisions of the policy makers. Actually this study attempted not only to bring to light the flagrant fluster of the man that selects wars as a safe shelter to reawake his disoriented identity, but also to divulge the malignant impacts of the imprudent policies of the autocrats, that under macabre misapprehension drown the toppled society in dystopian morasses to reach their insidious delusional purposes. This paper strove to delineate that modern society is entangled by the contaminated approaches and rancid aims of the authorities that bring about escalation of the excruciating sociospiritual agonies. In fact spiritually lacerated man under his depersonalized personality just pretends to be aware of the far-fetched sense of tranquility. In the modern world enlightenment is construed as being the slave of duplicitous bellicose thoughts of the authorities that wish to protect the devaluated values by having inhumane perspectives and initiating quasi-meliorative wars. In fact, human pauperized actualization of life and his mysterious demeanor provide a trenchant opportunity for the individuals to fulfill their life threatening notions by abusing charismatic expressions like dignity and chauvinism. Actually, power holders struggle to consolidate notoriously contradictive policies based on competitive nilpotent transcendence without regarding its ensuing dreadful possibilities, which may propagate schismatical notions in an oppressed society; the society which is destabilized by invariant injustice and shrouded with a terrifying ambiguity that impels it to reveal its unstable behavior.

\section{REFERENCES}

[1] Bloomfield, D \& Reilly, B. (1998). Democracy and Deep-Rooted Conflict: Options for Negotiators. Stockholm: International Institute for Democracy and Electoral Assistance, (International IDEA). www.idea.int/.../democracy_and_deep_rooted_conflict/.../Intr (retrieeved on 10/01/2013).

[2] Curtis, N. (2006). War and Social Theory World, Value and Identity. London: Palgrave Macmillan. interdisciplinary.net/ptb/wvw/wvw4/Boll\%20paper.pdf(retrieved on 22/12/2012).

[3] Fearon, D. J. (1999). What Is Identity (As We Now Use the Word)? Stanford: Stanford University.

[4] Feeley, M. M \& Rubin, E. (2008). Federalism: Political Identity and Tragic Compromise. Michigan: The University of Michigan Press. www.press.umich.edu/pdf/9780472116393-preface.pdf(retrieved on 09/11/2012).

[5] Gat, A. (1989). The Origins of Military Thought from the Enlightenment to Clausewitz. New York: Oxford University Press. www.jstor.org/stable/40106145(retrieved on 17/01/2013).

[6] Holsti, J. K. (1998). Peace And War: Armed Conflicts And International Order 1648-1989. New York: Cambridge University Press. www.olivialau.org/ir/archive/hol1.pdf(retrieved on 22/2/2013).

[7] Hooti, N. (2012). The Suppressed and Overlooked Sobs of the War under the sham Shield of Honor, Heroism and Patriotism. Journal of Basic and Applied Scientific Research, 2 (4) 4308-4311.

[8] Hurrell, A. (2007). On Global Order Power, Values and the Constitution of International Society. New York Oxford University Press. www.bpsr.org.br/english/.../BPSR_v2_n1_jun2008_07.pdf(retrieved on 06/11/2012).

[9] Lipschutz, d. R. (2000). After Authority War, Peace and Global Politics in the 21st Century. New York: State University of New York Press. www.powells.com/biblio?isbn=9780791445624(retrieved on 12/12/2012).

[10] Nowruzi, M \& Birjandi, P. (2011). Oral Reproduction of Stories (2). Tehran: The Organization for Researching and Composing University Textbooks in the Humanities (SAMT), The Center for Research and development in Humanities.

[11] Stewart, J. (2009). Public Policy Values. London: Palgrave Macmillan.

[12] Wallensteen, P. (2002). Understanding Conflict Resolution War, Peace and the Global System. London: SAGE Publications.

Noorbakhsh Hooti is an Associate Professor teaching at Razi University, Kermanshah, Iran. He has published numerous articles in the noted international journals. He has published a few books as well. He is the editor and reviewer of some well-known national and international journals.

Yazdan Mahmoudi is a BA student of English Literature studying at Razi University, Kermanshah, Iran 